Article

\title{
Evapotranspiration and Quantitative Partitioning of Spring Maize with Drip Irrigation under Mulch in an Arid Region of Northwestern China
}

\author{
Chenggong Xuan ${ }^{1,2}$, Risheng Ding ${ }^{1,2, *(D)}$, Jie Shao ${ }^{1,2}$ and Yanshuo Liu ${ }^{1,2}$ \\ 1 Center for Agricultural Water Research in China, China Agricultural University, Beijing 100083, China; \\ SY20173091430@cau.edu.cn (C.X.); S20183091539@cau.edu.cn (J.S.); SY20183091588@cau.edu.cn (Y.L.) \\ 2 National Field Scientific Observation and Research Station on Efficient Water Use of Oasis Agriculture, \\ Wuwei 733009, China \\ * Correspondence: dingrsh@cau.edu.cn; Tel.: +86-10-62738548
}

Citation: Xuan, C.; Ding, R.; Shao, J.; Liu, Y. Evapotranspiration and Quantitative Partitioning of Spring Maize with Drip Irrigation under Mulch in an Arid Region of Northwestern China. Water 2021, 13, 3169. https://doi.org/10.3390/ w13223169

Academic Editor: Arturo Alvino

Received: 12 October 2021

Accepted: 29 October 2021

Published: 10 November 2021

Publisher's Note: MDPI stays neutral with regard to jurisdictional claims in published maps and institutional affiliations.

Copyright: (c) 2021 by the authors. Licensee MDPI, Basel, Switzerland. This article is an open access article distributed under the terms and conditions of the Creative Commons Attribution (CC BY) license (https:// creativecommons.org/licenses/by/ $4.0 /)$.

\begin{abstract}
To examine evapotranspiration $\left(\mathrm{ET}_{\mathrm{C}}\right)$, soil evaporation $\left(\mathrm{E}_{\mathrm{S}}\right)$, and transpiration $\left(\mathrm{T}_{\mathrm{r}}\right)$, and partitioning of $\mathrm{ET}_{\mathrm{c}}$, a two-year field experiment was carried out in a maize field with drip irrigation under mulch in an arid region of northwestern China in 2017 and 2018. In the experiment we designed two treatments with full irrigation (T1) and growth stage-based strategic regulated deficit irrigation (T2). The applied irrigation of $\mathrm{T} 2$ was $40 \%$ of the $\mathrm{T} 1$ during both late vegetative and reproductive growth stages. Based on the measurements of soil water content (SWC) and $\mathrm{T}_{\mathrm{r}}$, a dual crop coefficient model (SIMDualK $\mathrm{C}_{\mathrm{C}}$ ) was calibrated and validated, and daily $\mathrm{ET}_{\mathrm{C}}, \mathrm{E}_{\mathrm{S}}$, and $\mathrm{T}_{\mathrm{r}}$ were estimated. The model can simulate well the dynamic variations of SWC and $\mathrm{T}_{\mathrm{r}}$. The calibrated basic crop coefficient at the initial, mid-season, and end growth stages was $0.2,1.15$, and 0.75 , respectively. The $\mathrm{ET}_{\mathrm{c}}$ was 507.9 and $519.1 \mathrm{~mm}$ for the T1 treatment, and 428.9 and $430.9 \mathrm{~mm}$ for the T2 treatment. The ratios of $\mathrm{T}_{\mathrm{r}}$ to $\mathrm{ET}_{\mathrm{c}}$ were higher for the two treatments, $\sim 90 \%$, for two years. Collectively, both drip irrigation under mulch and strategic deficit irrigation after canopy covering of the ground can significantly reduce the ineffective proportion of $\mathrm{ET}_{\mathrm{C}}$ and $\mathrm{E}_{\mathrm{s}}$.
\end{abstract}

Keywords: evapotranspiration; transpiration; maize; drip irrigation under mulch; strategic deficit irrigation

\section{Introduction}

Crop evapotranspiration $\left(\mathrm{ET}_{\mathrm{c}}\right)$ is one of the key indicators of field water management, crop irrigation scheduling, and planning and design of farmland water conservancy projects [1]. $\mathrm{ET}_{\mathrm{C}}$ is divided into two parts, soil evaporation $\left(\mathrm{E}_{\mathrm{S}}\right)$ and plant transpiration $\left(\mathrm{T}_{\mathrm{r}}\right)$. Among them, $E_{S}$, known as ineffective water consumption for crop growth and yield, can be decreased by ground coverage or proper irrigation management [2,3]. $T_{r}$, associated with photosynthetic carbon fixation through leaf pores, directly decides crop growth and the final yield [4]. However, as two water consumption processes in the farmland, $\mathrm{T}_{\mathrm{r}}$ and $E_{S}$ occur simultaneously, so it is difficult to carry out quantitative partitioning. Therefore, accurate determination of crop evapotranspiration and its components is of great significance for guiding field irrigation and improving the water use efficiency.

The FAO-56 dual crop coefficient approach is widely used because it can be used to accurately estimate crop evapotranspiration and realize quantitative partitioning of daily $E_{s}$ and $T_{r}$ [5]. Fan and Cai [6] and Lu et al. [7] demonstrated that $\mathrm{ET}_{\mathrm{c}}$ can be accurately estimated by the dual crop coefficient approach. A micro-lysimeter can be used to measure $\mathrm{E}_{\mathrm{s}}$, but owing to the limited measuring accuracy of the instrument, the accuracy can merely be controlled within 15-20\% [8]. Rosa et al. [9] developed a dual crop coefficient model $\left(\mathrm{SIMDualK}_{\mathrm{c}}\right.$ ) based on the dual crop coefficient approach, making it easier to partition $\mathrm{ET}_{\mathrm{C}}$. Many studies showed that the model has a highly accurate estimation of $\mathrm{ET}_{\mathrm{C}}$ and its components for wheat, maize, forage, tomato, chili, pea, cucumber, etc., in Brazil, Uruguay, Portugal, Spain, and North China [10-17]. 
Agricultural irrigation is a large water user in arid regions of Northwest China, which is short of water resources, so the use of a new effective water-saving irrigation technology is of great strategic significance for ensuring the water resources security and ecological safety of Northwest China [18]. Drip irrigation under mulch, which is a new type of water-saving technology integrating the advantages of the mulch film, such as soil temperature conservation, soil moisture conservation, yield increase, and the water-saving advantage of drip irrigation, can be used to decrease $E_{\mathrm{s}}$ and increase water use efficiency utilization during the initial stage of crop growth [19]. Thus, it has been widely used in arid regions of Northwest China. Previous studies have indicated that $\mathrm{E}_{\mathrm{s}}$ was reduced by $\sim 50 \%$ with plastic film mulch over the whole growing season [20-22]. Fan et al. [23] indicated that plastic mulch decreases the available energy and $\mathrm{ET}_{\mathrm{C}}$ of maize in an arid region of northwest China, and thus the crop coefficient $\left(\mathrm{K}_{\mathrm{c}}\right)$. Ding et al. [20] introduced a ground-mulching factor to modify the original soil evaporation coefficient in order to account for the reduction of the evaporation area by plastic film mulch. Zhang et al. [24] found that maize $\mathrm{ET}_{\mathrm{c}}$ with drip irrigation under mulch was reduced by $2.8-5.2 \%$, with reduced soil evaporation by $45.2 \%$ and increased transpiration by $8.9 \%$ in Northeastern China. However, there remain very few studies on $\mathrm{ET}_{\mathrm{c}}$ and its components related to the use of drip irrigation under mulch in arid regions of Northwest China.

Crop regulated deficit irrigation (RDI) is a water-saving and high-yield irrigation technology based on the relationship between crops and water. Moderate water deficit in the growth stage of crops can reduce crop water consumption but has a small impact on the final grain yield, thereby improving water use efficiency [25]. RDI reduces crop water consumption mainly by reducing crop growth and leaf area or canopy coverage, but a reduction in canopy coverage will increase the area of bare soil and increase soil evaporation. For example, water deficit in the seedling or early growth period would delay crop growth and canopy cover time, increasing the proportion of ineffective soil evaporation [26]. After the canopy covers the ground (or the leaf area index is greater than $3.0 \mathrm{~m}^{2} \mathrm{~m}^{-2}$ ), the implementation of the strategic stage of deficit adjustment can ensure the reduction of crop water consumption without increasing the proportion of soil evaporation [27]. Therefore, the timing of RDI is very important to reduce crop water consumption without increasing ineffective soil evaporation.

In this study, a two-year field experiment of maize with drip irrigation under mulch was carried out, and two water treatments were set up, namely full irrigation (T1) and strategic stage regulated deficit irrigation in the late growth and reproductive periods (T2). The SIMDualK $\mathrm{K}_{\mathrm{c}}$ model was used to estimate the $\mathrm{ET}_{\mathrm{c}}$ and $\mathrm{E}_{\mathrm{s}}$ and $\mathrm{T}_{\mathrm{r}}$ of maize during the whole growth period. The objectives were: (1) to quantify the proportion of $\mathrm{ET}_{\mathrm{C}}$ and $\mathrm{E}_{\mathrm{S}}$ and $T_{r}$ of maize with drip irrigation under mulch, and (2) to compare the differences in water use between the two treatments. These results provide a novel approach for efficient water management by strategic growth stage-based RDI in field maize.

\section{Materials and Methods}

\subsection{Experimental Area}

The experiment was conducted at the Shiyanghe Experiment Station, China Agricultural University in 2017 and 2018. The station is located in Liangzhou District, Wuwei, Gansu Province, northwest China ( $37^{\circ} 51^{\prime} \mathrm{N}, 102^{\circ} 52^{\prime} \mathrm{E}$, at an altitude of $\left.1581 \mathrm{~m}\right)$. The area has a typical continental temperate climate (arid inland desert climate) and abounds in photothermal resources. The annual sunshine duration exceeds $3000 \mathrm{~h}$; the frost-free season lasts for more than $150 \mathrm{~d}$; the annual average temperature is $8{ }^{\circ} \mathrm{C}$ and accumulated temperature above $0{ }^{\circ} \mathrm{C}$ is higher than $3550{ }^{\circ} \mathrm{C}$; the multi-year average wind speed is $1.3 \mathrm{~m} \mathrm{~s}^{-1}$; the multi-year average precipitation is $164 \mathrm{~mm}$; the groundwater depth is greater than $30 \mathrm{~m}$. The soil in the experimental area is light sandy loam. The average dry bulk density in the $100 \mathrm{~cm}$ soil layer of the root zone is $1.38 \mathrm{~g} \mathrm{~cm}^{-3}$, with an average field capacity $\left(\theta_{\mathrm{FC}}\right)$ of $0.32 \mathrm{~cm}^{3} \mathrm{~cm}^{-3}$ and permanent wilting point $\left(\theta_{\mathrm{WP}}\right)$ of $0.13 \mathrm{~cm}^{3} \mathrm{~cm}^{-3}$. 


\subsection{Experiment Design}

A randomized block experiment was used, with two irrigation treatments, i.e., full irrigation (T1) and regulated deficit irrigation (T2). Each treatment had three replicates, and there were six plots in total. Each plot had a size of $7 \times 4.5 \mathrm{~m}$, and the plots stayed unchanged in terms of size and treatment location in the two years. The planting crop was spring maize (Xianyu 335), which was sown on 29 April 2017, and the harvest date was 24 September, and the growth period was 148 days; in 2018, the planting was carried out on 26 April, the harvest date was 24 September, and the length of the growth period was 151 days. We used drip irrigation under the film, and each plot was laid with three white transparent films (Figure 1). The film width was $1.4 \mathrm{~m}$, and each film had three drip irrigation tapes. The seeds were sown on one side of the drip irrigation tapes under the mulch, with a pore diameter of $5 \mathrm{~cm}$, row spacing of $50 \mathrm{~cm}$, and plant spacing of $25 \mathrm{~cm}$. The film coverage rate was one minus the sum of the bare soil area per unit area and the film hole area, which was about $80 \%$. The dripper flow rate was $2.5 \mathrm{~L} \mathrm{~h}^{-1}$, the dripper spacing was $30 \mathrm{~cm}$, and the working pressure was $0.1 \mathrm{MPa}$. Nitrogen fertilizer of $250 \mathrm{~kg} \mathrm{ha}^{-1}$, phosphate fertilizer of $60 \mathrm{~kg} \mathrm{ha}^{-1}$, and potassium fertilizer of $139 \mathrm{~kg} \mathrm{ha}^{-1}$ were applied during the whole growth period. Nitrogen fertilizer of $60 \mathrm{~kg} \mathrm{ha}^{-1}$ was applied before sowing, and the remaining nitrogen fertilizer was applied four times. Other agronomic measures were consistent with local field management.
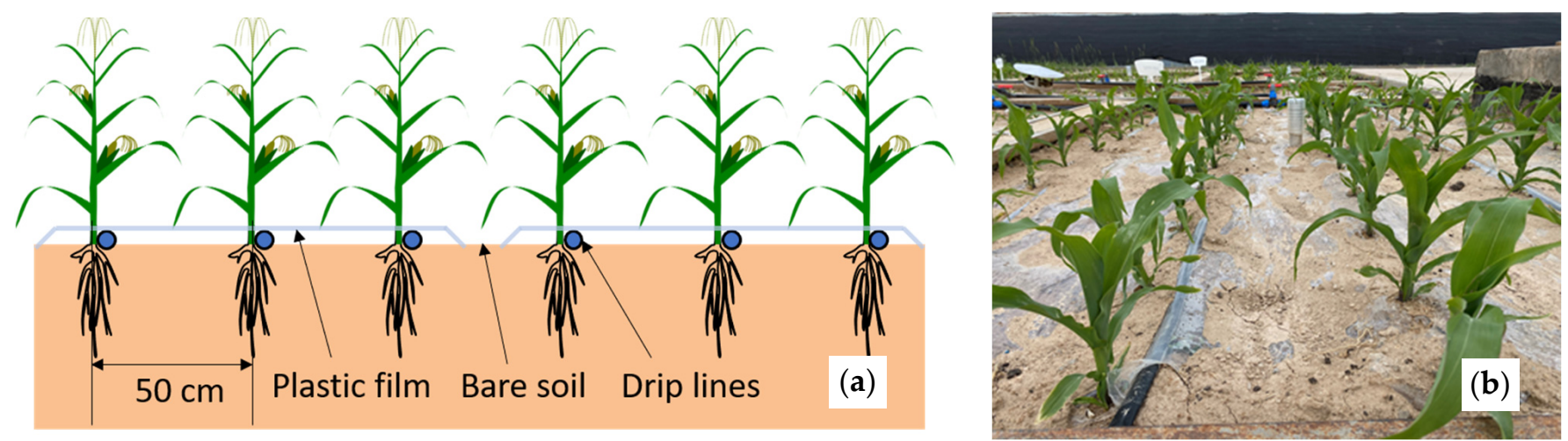

Figure 1. Schematic diagram of maize planting with drip irrigation under mulch (a) and photo (b).

\subsection{Irrigation Management}

For the T1 treatment, irrigation scheduling was designed based on both the water requirements of the crop estimated by the FAO-56 approach and on the measured soil water content. The irrigation amount was set to $100 \% \mathrm{ET}_{\mathrm{C}}$ or $\theta_{\mathrm{FC}}$. The water amount for the $\mathrm{T} 2$ treatment was $40 \%$ of that for $\mathrm{T} 1$ during both the late vegetative and reproductive growth stages and irrigated to $\theta_{\mathrm{FC}}$ both at the seedling stage and the filling stage. For T1 treatment, unified irrigation was performed before the soil water content decreased below the level of readily available water $(\mathrm{RAW})$. $\mathrm{ET}_{\mathrm{C}}$ was determined according to the reference evapotranspiration $\left(\mathrm{ET}_{0}\right)$ and crop coefficient $\left(\mathrm{K}_{\mathrm{c}}\right)$, while $\mathrm{K}_{\mathrm{c}}$ was determined by canopy cover $\left(f_{c}\right)$ calculation. Table 1 shows the irrigation time and amount for T1 and T2 in 2017 and 2018. The total irrigation amount for T1 and T2 was 433 and $337 \mathrm{~mm}$ in 2017, and 382 and $347 \mathrm{~mm}$ in 2018, respectively. 
Table 1. Irrigation scheduling for maize with drip irrigation under mulch for two water treatments (T1 and T2) during the whole growth period of maize in 2017 and 2018.

\begin{tabular}{|c|c|c|c|}
\hline \multirow{2}{*}{ Years } & \multirow{2}{*}{ Dates } & \multicolumn{2}{|c|}{ Irrigation Depth (mm) } \\
\hline & & T1 & $\mathrm{T} 2$ \\
\hline \multirow{8}{*}{2017} & $5 / 3$ & 30 & 30 \\
\hline & $5 / 31$ & 17 & 16 \\
\hline & $6 / 18-6 / 19$ & 40 & 41 \\
\hline & $6 / 30-7 / 1$ & 55 & 22 \\
\hline & $7 / 10-7 / 11$ & 53 & 21 \\
\hline & $7 / 22-7 / 24$ & 120 & 120 \\
\hline & $8 / 8$ & 43 & 57 \\
\hline & $8 / 31$ & 75 & 30 \\
\hline \multirow{8}{*}{2018} & $4 / 27$ & 30 & 30 \\
\hline & $5 / 9$ & 21 & 21 \\
\hline & $6 / 10$ & 50 & 51 \\
\hline & $6 / 23$ & 60 & 25 \\
\hline & $6 / 30$ & 41 & 17 \\
\hline & $7 / 9$ & 37 & 16 \\
\hline & $7 / 18-7 / 19$ & 68 & 100 \\
\hline & $8 / 15-8 / 16$ & 75 & 87 \\
\hline
\end{tabular}

\subsection{Data Measurements}

The meteorological data were measured by a 2 m-high automatic weather station (Hobo, Onset Computer Corporation, Cape Cod, MA, USA) at the Experimental Station. The data included solar radiation $\left(R_{s}\right)$, air temperature $\left(T_{a}\right)$, relative humidity $(R H), 2 \mathrm{~m}$ wind speed $\left(\mathrm{u}_{2}\right)$, and precipitation $(\mathrm{P})$ recorded every $15 \mathrm{~min}$. $\mathrm{ET}_{0}$ was calculated using the FAO-56 Penman-Monteith equation [5]. The average wind speed during the growth period was $0.7 \mathrm{~m} \mathrm{~s}^{-1}$ in 2017 and $0.66 \mathrm{~m} \mathrm{~s}^{-1}$ in 2018. The average $\mathrm{R}_{\mathrm{s}}$ during the growth period was $223.54 \mathrm{~W} \mathrm{~m}^{-2}$ in 2017 and $213.4 \mathrm{~W} \mathrm{~m}^{-2}$ in 2018. Figure 2 shows the $\mathrm{ET}_{0}, \mathrm{P}$, and maximum and minimum $\mathrm{T}_{\mathrm{a}}\left(\mathrm{T}_{\max }\right.$, and $\left.\mathrm{T}_{\min }\right)$ in 2017 and 2018.
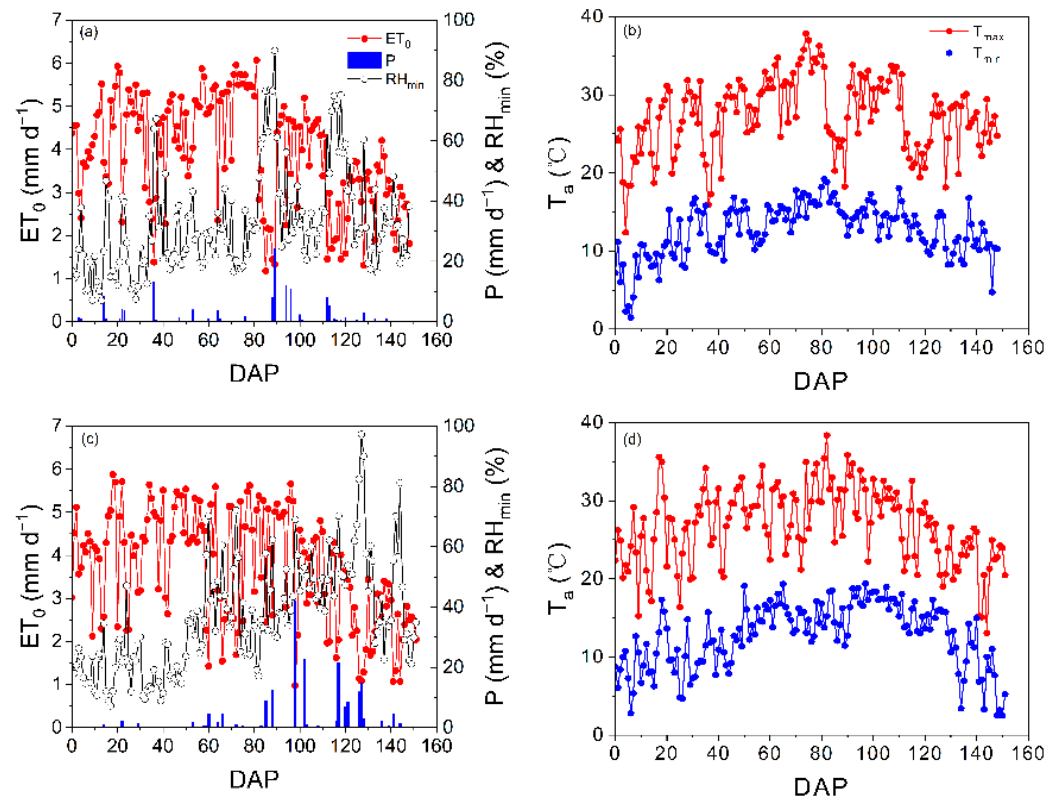

Figure 2. Daily variations of reference evapotranspiration $\left(\mathrm{ET}_{0}\right)$, precipitation $(\mathrm{P})$, daily minimum relative humidity $\left(\mathrm{RH}_{\min }\right)$, and maximum and minimum air temperature ( $\mathrm{T}_{\max }$ and $\left.\mathrm{T}_{\min }\right)$ with days after planting (DAP) during the whole growth period of maize in $2017(\mathbf{a}, \mathbf{b})$ and $2018(\mathbf{c}, \mathbf{d})$. 
The volumetric soil water content $\left(\mathrm{SWC}, \mathrm{cm}^{3} \mathrm{~cm}^{-3}\right.$ ) was measured in $10 \mathrm{~cm}$ increments in depths of 0-200 cm using a neutron probe (CPN-503 Hydroprobe, InstroTek, San Francisco, CA, USA). One neutron tube was installed the center of each plot. SWC was measured every 7-10 d, and an additional measurement was made before and after irrigation and after rain. The soil drying method was used for calibration.

Maize transpiration was measured by the wrapped sap flowmeter Flow32-1k (Dynamax Inc., Houston, TX, USA). Three uniformly growing maize plants in each plot were selected for wrapping. Before wrapping, the stem diameter of maize at the wrapping site was measured with a vernier caliper with an accuracy of $0.01 \mathrm{~mm}$. An average value was used to calculate the cross-sectional area of the maize stalk and then the cross-sectional area was converted into the transpiration of the plot based on the leaf area index as follows:

$$
\mathrm{T}_{\mathrm{r}}=\frac{1}{\mathrm{~N}} \sum_{\mathrm{i}=1}^{\mathrm{n}} \frac{\mathrm{Q}_{\mathrm{di}}}{\mathrm{LA}_{\mathrm{i}}} \mathrm{LAI}
$$

where $T_{\mathrm{r}}$ is the transpiration rate of the plot $\left(\mathrm{mm} \mathrm{d}^{-1}\right) ; \mathrm{Q}_{\mathrm{di}}$ is the sap flow per plant of the $\mathrm{i}$-th plant $\left(\mathrm{L} \mathrm{d}^{-1}\right)$; $\mathrm{LA}_{\mathrm{i}}$ is the leaf area of the $\mathrm{i}$-th plant $\left(\mathrm{m}^{2}\right)$; $\mathrm{LAI}$ is the leaf area index $\left(\mathrm{m}^{2} \mathrm{~m}^{-2}\right)$.

The crop height $\left(h_{c}\right)$ was measured with a ruler every $10-15 \mathrm{~d}$. The canopy coverage $\left(f_{c}\right)$ was measured by photographing above the crop perpendicular to the ground. The ratio of the green area to the total area in the photo was equal to $f_{c}$. The root zone depth $\left(Z_{\mathrm{r}}\right)$ was measured at each growth stage by root drilling.

\subsection{Quantitative Partitioning of ET $T_{c}$ Using the SIMDualKc Model}

The SIMDualKc model calculates daily crop $\mathrm{ET}_{\mathrm{c}}$ by considering both $\mathrm{E}_{\mathrm{S}}$ and $\mathrm{T}_{\mathrm{r}}$ based on the soil water balance and dual $K_{c}$ method $[9,28]$. In the model, actual crop ET $_{c}$ is computed as follows:

$$
\mathrm{ET}_{\mathrm{c}}=\left(\mathrm{K}_{\mathrm{s}} \cdot \mathrm{K}_{\mathrm{cb}}+\mathrm{K}_{\mathrm{e}}\right) \mathrm{ET}_{0}
$$

where $\mathrm{K}_{\mathrm{cb}}$ is the basal crop coefficient, $\mathrm{K}_{\mathrm{e}}$ is the soil evaporation coefficient, $\mathrm{K}_{\mathrm{s}}$ is the water stress coefficient $[0,1]$, and $\mathrm{ET}_{0}$ is the reference evapotranspiration. The SIMDualK $\mathrm{C}_{\mathrm{c}}$ model was used to calculate $\mathrm{ET}_{\mathrm{C}}$ and its components by simulating the dynamic variations of SWC in the root zone. The input data of the model included soil data (field water holding capacity, withering coefficient, saturated moisture content), meteorological data, crop growth data (start and end dates of each growth stage, root depth, plant height, canopy coverage), and irrigation data (irrigation amount and date). The model also considers the effects of mulching film coverage, groundwater recharge, surface runoff, and deep percolation on $\mathrm{T}_{\mathrm{r}}$. Before running the model, the total evaporable water (TEW), readily evaporable water $(\mathrm{REW})$, depth of evaporation layer $\left(Z_{\mathrm{e}}\right)$, basic crop coefficient $\left(\mathrm{K}_{\mathrm{cb}}\right)$, and soil water depletion fraction $(\mathrm{p})$ were calibrated.

To calibrate the model parameters, according to the FAO-56 method $[5,28]$, the whole growth period of maize was divided into the initial stage (from seed sowing to $f_{c}=10 \%$ ), development stage $\left(10 \%<\mathrm{f}_{\mathrm{c}}<80 \%\right)$, mid-season stage (from $\mathrm{f}_{\mathrm{c}}=80 \%$ to maturing) and late-season stage (from maturing to harvest). The average growth indicators of maize in 2017 and 2018 are shown in Table 2 for each treatment. The parameters were calibrated by the trial-and-error method. The simulated soil water content was compared with the measured value. When the error between the simulated and the measured values reached a minimum, the parameter calibration process ended [28,29]. In this study, the measured SWC of 2017 was used for parameter calibration while the data of 2018 were used for verification. The initial values of TEW, $R E W, Z_{e}, K_{c b}$, and $p$ were set to be equal to the values recommended by Allen et al. [5] and corrected according to the local meteorological conditions and crop factors. Because drip irrigation under mulch was used, the irrigation water-soil wetting ratio $\left(f_{w}\right)$ was 0.4 and the film mulching rate was 0.6 . The irrigation amount did not exceed the water capacity of the root layer, so deep-water seepage or deep percolation was not taken into consideration. Surface runoffs were not detected in the two years. A simulation was performed using the given $\mathrm{K}_{\mathrm{cb}}$ and $\mathrm{p}$. Since the $\mathrm{T} 2$ treatment 
caused some limitations on the growth of maize, the $\mathrm{f}_{\mathrm{c}}$ of the T2 treatment decreased somewhat at the mid-season and late-season stages compared with T1. Therefore, $\mathrm{K}_{\mathrm{cb}}$ was adjusted according to the mid-and late-season stages' measured values of $\mathrm{f}_{\mathrm{c}}$.

Table 2. Growth traits for two water treatments (T1 and T2) during the whole growth period of maize in 2017 and 2018.

\begin{tabular}{|c|c|c|c|c|c|c|c|}
\hline \multirow{2}{*}{ Traits } & \multirow{2}{*}{ Years } & \multirow{2}{*}{ Treatments } & \multicolumn{5}{|c|}{ Growth Stages } \\
\hline & & & Initial & Development & Mid-Season & Late-Season & Whole Season \\
\hline \multirow{4}{*}{ Growth length (d) } & \multirow{2}{*}{2017} & T1 & 27 & 27 & 64 & 30 & 148 \\
\hline & & $\mathrm{T} 2$ & 28 & 29 & 58 & 33 & 148 \\
\hline & \multirow{2}{*}{2018} & T1 & 32 & 25 & 64 & 30 & 151 \\
\hline & & T2 & 32 & 28 & 59 & 32 & 151 \\
\hline \multirow{4}{*}{ Plant height (m) } & \multirow{2}{*}{2017} & T1 & 0.3 & 1.5 & 2.9 & 3.1 & \multirow{4}{*}{ - } \\
\hline & & $\mathrm{T} 2$ & 0.29 & 1.5 & 2.4 & 2.4 & \\
\hline & \multirow{2}{*}{2018} & T1 & 0.4 & 1.4 & 2.9 & 3.1 & \\
\hline & & T2 & 0.4 & 1.2 & 2.7 & 2.7 & \\
\hline \multirow{4}{*}{ Root depth (m) } & \multirow{2}{*}{2017} & $\mathrm{~T} 1$ & 0.1 & 0.4 & 0.74 & 0.74 & \multirow{4}{*}{-} \\
\hline & & T2 & 0.2 & 0.5 & 0.65 & 0.65 & \\
\hline & \multirow{2}{*}{2018} & T1 & 0.2 & 0.44 & 0.7 & 0.7 & \\
\hline & & $\mathrm{T} 2$ & 0.25 & 0.5 & 0.7 & 0.7 & \\
\hline \multirow{4}{*}{ Canopy cover } & \multirow{2}{*}{2017} & $\mathrm{~T} 1$ & 0.1 & 0.97 & 0.93 & 0.6 & \multirow{4}{*}{-} \\
\hline & & $\mathrm{T} 2$ & 0.1 & 0.9 & 0.85 & 0.56 & \\
\hline & \multirow{2}{*}{2018} & T1 & 0.1 & 0.95 & 0.9 & 0.6 & \\
\hline & & T2 & 0.1 & 0.88 & 0.85 & 0.55 & \\
\hline
\end{tabular}

Model performance was assessed using the regression coefficient (b), determination coefficient $\left(R^{2}\right)$, root mean square error (RMSE), maximum absolute error $\left(E_{\max }\right)$, average absolute error (AAE), Willmott index of agreement $\left(\mathrm{d}_{\mathrm{IA}}\right)$, and Nash and Sutcliffe modeling efficiency $(\mathrm{EF})$ between the simulated value and the measured value [13,30-33]. Among them, $b, R^{2}, d_{I A}$, and EF were closer to 1.0, and RMSE, $E_{\max }$, and AAE were closer to 0, indicating that the fitting effect was better.

\section{Results and Discussion}

Table 3 shows the initial and calibration values of the main model parameters. After calibration, the $\mathrm{K}_{\mathrm{cb}}$ of maize with drip irrigation under mulch at the initial stage $\left(\mathrm{K}_{\mathrm{cb} \text {-ini }}\right)$, mid-season stage $\left(\mathrm{K}_{\mathrm{cb} \text {-mid }}\right)$, and late season stage $\left(\mathrm{K}_{\mathrm{cb}-e n d}\right)$ were equal to $0.2,1.15$, and 0.55 , respectively. The values of $\mathrm{K}_{\mathrm{cb}}$ obtained in this study were similar to those in the existing studies and sit within the reviewed and updated range of $\mathrm{K}_{\mathrm{cb}}$ for field maize based on accurate crop ETc measurement and FAO56 method by Pereira et al. [34]. Chauhdary et al. [35] presented $\mathrm{K}_{\mathrm{cb} \text {-mid }}=0.93, \mathrm{~K}_{\mathrm{cb} \text {-end }}=0.47$ for dripped maize with high grain moisture; they used the SALTMED model and gravimetric SWC measurements in Faisalabad, Pakistan. The experimental results achieved by Gimenez et al. [11] in western Uruguay showed that $\mathrm{K}_{\mathrm{cb} \text {-ini }}=0.15, \mathrm{~K}_{\mathrm{cb}-\text { mid }}=1.05$, and $\mathrm{K}_{\mathrm{cb}-\mathrm{end}}=0.3$. Martins et al. [36] studied maize with sprinkling irrigation and drip irrigation under organic film in southern Brazil and showed that $\mathrm{K}_{\mathrm{cb} \text {-ini }}=0.2, \mathrm{~K}_{\mathrm{cb} \text {-mid }}=1.12$, and $\mathrm{K}_{\mathrm{cb} \text {-end }}=0.2$. Rodrigues et al. [37] conducted a study on maize under full irrigation and deficit drip irrigation in Portugal and found that $\mathrm{K}_{\mathrm{cb} \text {-ini }}=0.15, \mathrm{~K}_{\mathrm{cb}-\mathrm{mid}}=1.15$, and $\mathrm{K}_{\mathrm{cb}-\mathrm{end}}=0.4$. Paredes et al. [38], in Portugal, showed by using the AquaCrop model that $\mathrm{K}_{\mathrm{c} T \mathrm{r}, \mathrm{x}}=1.18$. Paredes et al. [12] in 2014 showed that $\mathrm{K}_{\mathrm{cb} \text {-ini }}=0.15, \mathrm{~K}_{\mathrm{cb} \text {-mid }}=1.15$, and $\mathrm{K}_{\mathrm{cb} \text {-end }}=0.3$. Yan et al. [39] studied summer maize under different drip irrigation conditions using the $\mathrm{SIMDualK}_{\mathrm{c}}$ model in Yangling, Shaanxi, concluding that $\mathrm{K}_{\mathrm{cb} \text {-ini }}=0.15, \mathrm{~K}_{\mathrm{cb} \text {-mid }}=1.13$, and $\mathrm{K}_{\mathrm{cb} \text {-end }}=0.2$. Zhao et al. [40] studied summer maize in Beijing, concluding that $\mathrm{K}_{\mathrm{cb}-\mathrm{ini}}=0.2, \mathrm{~K}_{\mathrm{cb} \text {-mid }}=1.1$, and $\mathrm{K}_{\mathrm{cb}-\text {-end }}=0.45$. Li et al. [25] studied maize by drip irrigation under mulch in northeastern Inner Mongolia, concluding that $\mathrm{K}_{\mathrm{cb} \text {-ini }}=0.15, \mathrm{~K}_{\mathrm{cb} \text {-mid }}=1.05$, and $\mathrm{K}_{\mathrm{cb} \text {-end }}=0.4$. The slightly higher $\mathrm{K}_{\mathrm{cb} \text {-end }}$ might be due to the incomplete senescence of maize. 
Table 3. Initial and calibrated values of key parameters for the SIMDualKc model.

\begin{tabular}{ccc}
\hline Parameters & Initial Values & Calibrated \\
\hline Crop parameters & & \\
$\mathrm{K}_{\mathrm{cb} \text {-ini }}$ & 0.15 & $\mathbf{0 . 2}$ \\
$\mathrm{K}_{\text {cb-mid }}$ & 1.15 & 1.15 \\
$\mathrm{~K}_{\text {cb-end }}$ & 0.50 & $\mathbf{0 . 5 5}$ \\
p & 0.55 & 0.55 \\
Pmid & 0.55 & 0.55 \\
Pend & 0.55 & 0.55 \\
Soil parameters & & \\
REW (mm) & 10 & $\mathbf{1 2}$ \\
TEW (mm) & 30 & 30 \\
Z $_{\mathrm{e}}(\mathrm{m})$ & 0.12 & $\mathbf{0 . 1 5}$ \\
\hline
\end{tabular}

Note: $\mathrm{K}_{\mathrm{cb}}$ and $\mathrm{p}$ are the maize basal crop coefficient and the soil-water depletion fraction, respectively, for no stress at the initial (ini), mid-season (mid) and late-season (end) stages; REW and TEW are readily and total evaporable water, respectively; and $Z_{\mathrm{e}}$ is the depth of the soil evaporation layer. The emboldened values are calibrated parameters that are different from the initial ones.

The measured and simulated SWC in the root zone of the two treatments in 2017 and 2018 are shown in Figure 3. The goodness-of-fit statistic of calibration and verification are shown in Table 4. The simulated value and measured SWC fit well. The simulated SWC can capture a dynamic process in which the SWC increased in a short period with irrigation or rainfall, and then gradually decreased due to $\mathrm{ET}_{\mathrm{c}}$. The regression coefficient $\mathrm{b}$ was 0.96-1.07, $\mathrm{R}^{2}$ was 0.84-0.95, RMSE was $0.005-0.008 \mathrm{~cm}^{3} \mathrm{~cm}^{-3}$, AAE 0.01 was $\mathrm{cm}^{3} \mathrm{~cm}^{-3}$, $E_{\max } 0.025$ was $\mathrm{cm}^{3} \mathrm{~cm}^{-3}$, and $\mathrm{d}_{\mathrm{IA}}$ reached up to 0.96 , which was better than the results of the study of rain-fed maize in Inner Mongolia by Wu et al. [41]. These results were slightly lower than those found by Zhao et al. [39] on summer maize in Beijing $(b=0.91-1.01$, $\mathrm{R}^{2}=0.87-0.93$ ), but the relative error of SWC in this study was lower than $10 \%$, suggesting that the SIMDualK $\mathrm{C}_{\mathrm{c}}$ model was accurately able to calculate SWC and can be used to calculate $\mathrm{ET}_{\mathrm{c}}$ of maize and its partitioning [9].
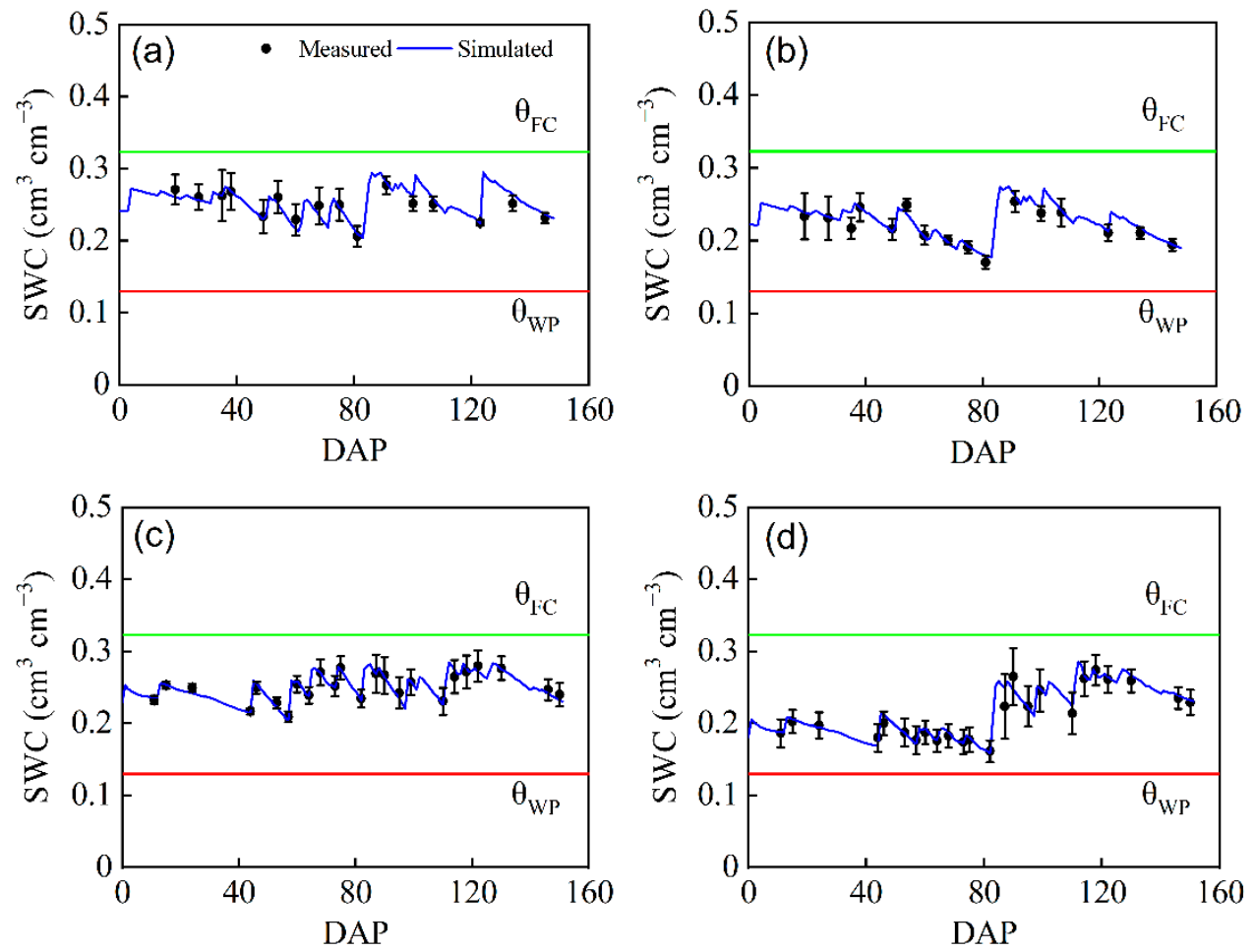

Figure 3. Measured and simulated seasonal soil water content (SWC) for two water treatments (T1 and T2) with days after planting (DAP) during the whole growth period of maize in $2017(\mathbf{a}, \mathbf{b})$ and $2018(\mathbf{c}, \mathbf{d})$. 
Table 4. Statistical indicators of goodness-of-fit between measured and simulated seasonal soil water content (SWC) for the two treatments (T1 and T2) in 2017 and 2018.

\begin{tabular}{|c|c|c|c|c|c|c|c|c|}
\hline Years & Treatments & $\mathbf{b}$ & $\mathbf{R}^{2}$ & $\operatorname{RMSE}\left(\mathrm{cm}^{3} \cdot \mathrm{cm}^{-3}\right)$ & $\operatorname{AAE}\left(\mathrm{cm}^{3} \cdot \mathrm{cm}^{-3}\right)$ & $\mathrm{E}_{\max }\left(\mathrm{cm}^{3} \cdot \mathrm{cm}^{-3}\right)$ & $\mathrm{d}_{\mathrm{IA}}$ & EF \\
\hline \multirow{2}{*}{2017} & $\mathrm{~T} 1$ & 0.98 & 0.84 & 0.008 & 0.006 & 0.013 & 0.96 & 0.82 \\
\hline & $\mathrm{T} 2$ & 0.96 & 0.90 & 0.008 & 0.006 & 0.022 & 0.97 & 0.89 \\
\hline \multirow{2}{*}{2018} & $\mathrm{~T} 1$ & 1.07 & 0.95 & 0.005 & 0.004 & 0.010 & 0.99 & 0.94 \\
\hline & $\mathrm{T} 2$ & 1.00 & 0.95 & 0.008 & 0.006 & 0.025 & 0.99 & 0.94 \\
\hline
\end{tabular}

Note: $b$, linear regression coefficient; $\mathrm{R}^{2}$, coefficient of determination; RMSE, root mean square error; AAE, average absolute error; $\mathrm{E}_{\mathrm{max}}$, maximum absolute error; $\mathrm{d}_{\mathrm{IA}}$, Willmott index of agreement; and $\mathrm{EF}$, the Nash and Sutcliffe modeling efficiency.

The $E_{S}, T_{r}$, and $E_{C}$ of maize were estimated using the calibrated and verified SIMDualK $_{c}$ model. Daily $\mathrm{K}_{\mathrm{e}}, \mathrm{K}_{\mathrm{cb}}$, and $\mathrm{K}_{\mathrm{cbadj}}$, as well as $\mathrm{E}_{\mathrm{s}}, \mathrm{T}_{\mathrm{r}}$, and $\mathrm{ET}_{\mathrm{c}}$, and measured $\mathrm{T}_{\mathrm{r}}$ for $\mathrm{T} 1$ and $\mathrm{T} 2$ in 2017 and 2018 are shown in Figures 4 and 5, respectively. The goodness-of-fit statistics of the measured and simulated $\mathrm{T}_{\mathrm{r}}$ are presented in Table 5. The simulated and measured $\mathrm{T}_{\mathrm{r}}$ had the same changing trend during the growth period. The $\mathrm{b}$ was $0.91-1.04, \mathrm{R}^{2}$ was 0.91-0.97, RMSE was 0.366-0.389 $\mathrm{mm} \mathrm{d}^{-1}$, AAE $<0.5 \mathrm{~mm} \mathrm{~d}^{-1}, \mathrm{E}_{\max }$ was $1.163 \mathrm{~mm} \mathrm{~d}^{-1}$, $\mathrm{d}_{\mathrm{IA}}>0.95$, and EF 0.80-0.91. Although $\mathrm{T}_{\mathrm{r}}$ was only verified during the mid-to-late growth period, we concluded that the model can estimate $T_{r}$ throughout the growth period since it accurately simulated SWC throughout the growth period. Qiu et al. [42] compared tomato $\mathrm{ET}_{\mathrm{C}}$ measured by a lysimeter with SIMDualK $\mathrm{C}_{\mathrm{c}}$ simulations and found that $\mathrm{b}$ was 0.91-1.13 and $\mathrm{R}^{2}$ was 0.55-0.82. Yan et al. [17] compared measured $\mathrm{T}_{\mathrm{r}}$ values of greenhouse cucumber with simulations and demonstrated that the $\mathrm{R}^{2}$ was 0.89-0.92 and RMSE was $0.36-0.51 \mathrm{~mm} \mathrm{~d}^{-1}$. Our results were similar to those of previous studies. Overall, after being calibrated, the SIMDualK $\mathrm{C}_{\mathrm{c}}$ model can better simulate the changes in $\mathrm{ET}_{\mathrm{C}}$ of maize with drip irrigation under mulch during the growth period.
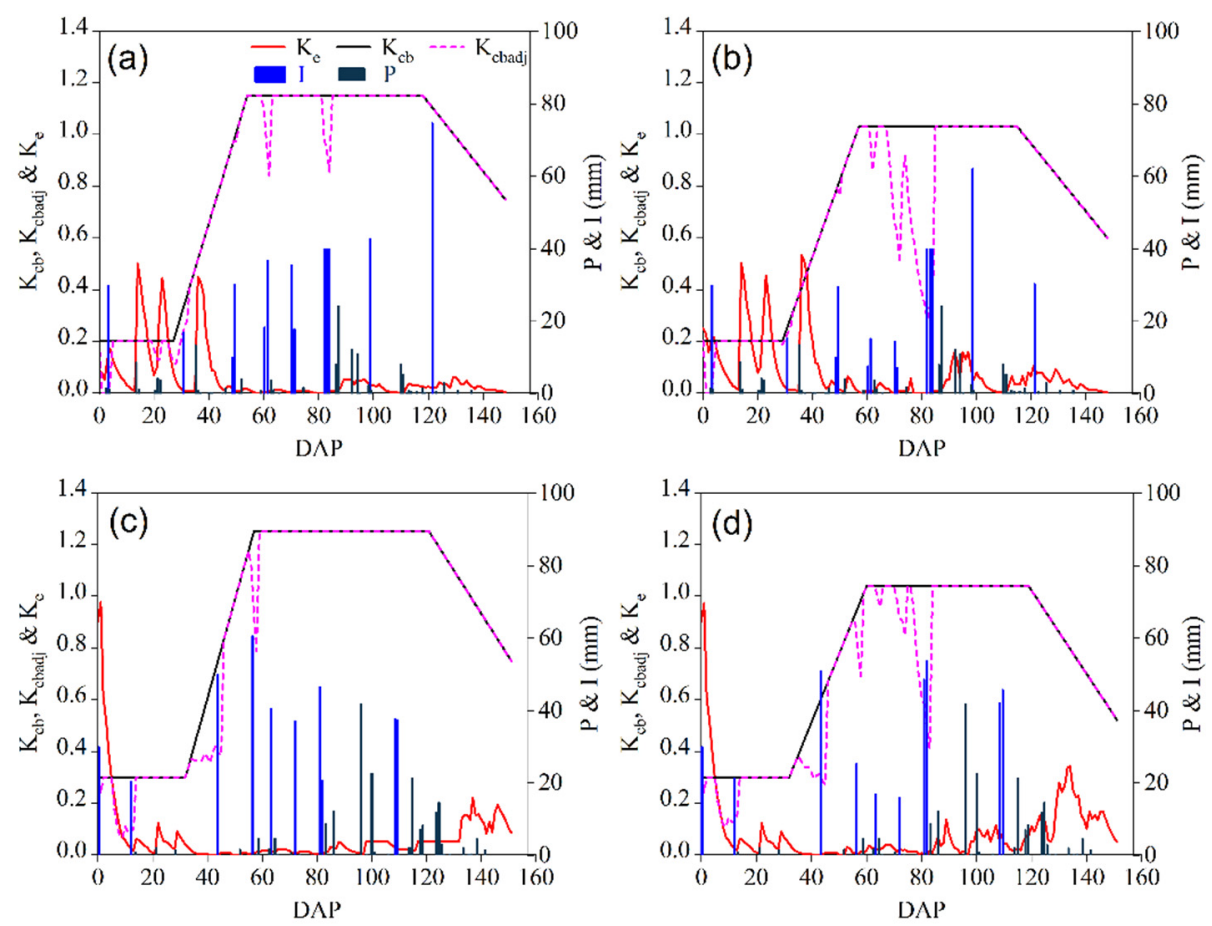

Figure 4. Dynamic variations of basic crop coefficient $\left(\mathrm{K}_{\mathrm{cb}}\right)$, actual adjustment $\mathrm{K}_{\mathrm{cb}}\left(\mathrm{K}_{\mathrm{cbadj}}\right)$ and soil evaporation coefficient $\left(\mathrm{K}_{\mathrm{e}}\right)$ for two water treatments (T1 and T2) with days after planting (DAP) during the whole growth period of maize in $(\mathbf{a}, \mathbf{b})$ and $2018(\mathbf{c}, \mathbf{d})$. 

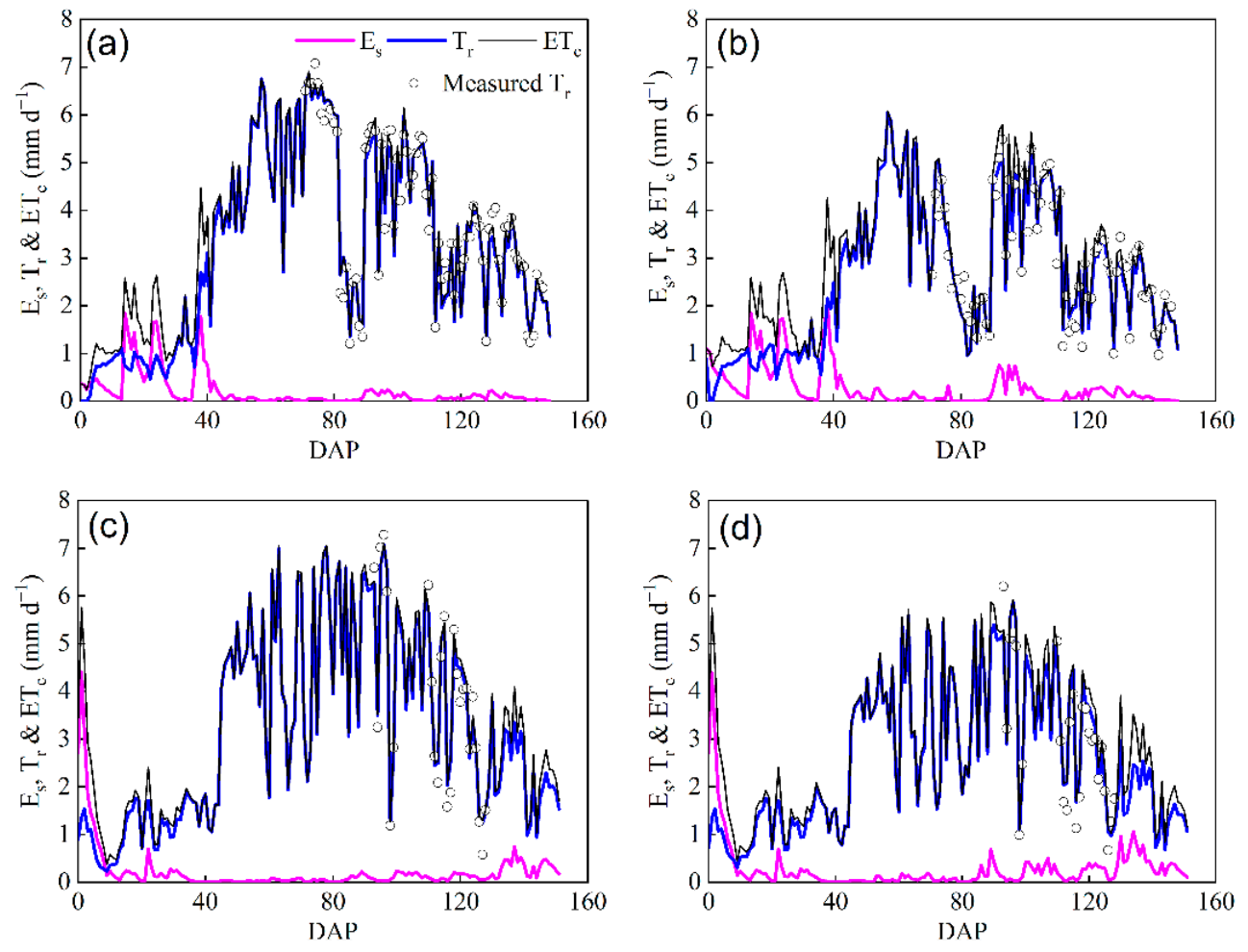

Figure 5. Seasonal variations of simulated evapotranspiration $\left(\mathrm{ET}_{\mathrm{c}}\right)$, transpiration $\left(\mathrm{T}_{\mathrm{r}}\right)$, and soil evaporation $\left(E_{s}\right)$, and measured $T_{r}$ for two water treatments (T1 and T2) with days after planting (DAP) during the whole growth period of maize in $(\mathbf{a}, \mathbf{b})$ and $2018(\mathbf{c}, \mathbf{d})$.

Table 5. Statistical indicators of goodness-of-fit between measured and simulated seasonal plant transpiration $\left(T_{r}\right)$ for the two treatments (T1 and T2) in 2017 and 2018.

\begin{tabular}{ccccccccc}
\hline \multirow{2}{*}{ Years } & Treatments & $\mathbf{b}$ & $\mathbf{R}^{\mathbf{2}}$ & $\mathbf{R M S E}\left(\mathbf{m m} \cdot \mathbf{d}^{-\mathbf{1}}\right)$ & $\mathbf{A A E}\left(\mathbf{m m} \cdot \mathbf{d}^{-\mathbf{1}}\right)$ & $\mathbf{E}_{\max }\left(\mathbf{m m} \cdot \mathbf{d}^{-1}\right)$ & $\mathbf{d}_{\text {IA }}$ & $\mathbf{E F}$ \\
\hline \multirow{2}{*}{2017} & T1 & 0.99 & 0.95 & 0.366 & 0.294 & 1.060 & 0.97 & 0.88 \\
& T2 & 1.00 & 0.91 & 0.379 & 0.293 & 1.163 & 0.95 & 0.80 \\
\multirow{2}{*}{2018} & T1 & 0.91 & 0.97 & 0.367 & 0.310 & 0.709 & 0.98 & 0.91 \\
& T2 & 1.04 & 0.95 & 0.389 & 0.346 & 0.649 & 0.96 & 0.82 \\
\hline
\end{tabular}

Note: $b$, linear regression coefficient; $\mathrm{R}^{2}$, coefficient of determination; RMSE, root mean square error; AAE, average absolute error; $E_{\max }$ maximum absolute error; $d_{I A}$, Willmott index of agreement; and EF, the Nash and Sutcliffe modeling efficiency.

$\mathrm{E}_{\mathrm{S}}$ and $\mathrm{T}_{\mathrm{r}}$ values and their ratios to $\mathrm{ET}_{\mathrm{c}}$ in different growth stages of maize are shown in Table 6. In 2017, the $\mathrm{ET}_{\mathrm{C}}$ for T1 and T2 was 507.9 and $428.9 \mathrm{~mm}$, $\mathrm{E}_{\mathrm{s}}$ was 32.0 and $43.6 \mathrm{~mm}$, and $\mathrm{T}_{\mathrm{r}}$ was 476.0 and $385.3 \mathrm{~mm}$, respectively during the whole growth period of maize. In 2018, the $\mathrm{ET}_{\mathrm{c}}$ for $\mathrm{T} 1$ and $\mathrm{T} 2$ was 519.1 and $430.9 \mathrm{~mm}$, $\mathrm{E}_{\mathrm{s}}$ was 35.2 and $43.4 \mathrm{~mm}$, and $\mathrm{T}_{\mathrm{r}}$ was 484.0 and $387.5 \mathrm{~mm}$, respectively during the whole growth period of maize. There were large differences in $\mathrm{ET}_{\mathrm{c}}, \mathrm{E}_{\mathrm{s}}$, and $\mathrm{T}_{\mathrm{r}}$ between $\mathrm{T} 1$ and $\mathrm{T} 2$. In particular, there was a difference of $90.7-96.5 \mathrm{~mm}$ in $\mathrm{T}_{\mathrm{r}}$, which occurred in the middle growth period. The pattern was similar for two years, which suggests that drip irrigation with film mulching can significantly reduce soil evaporation regardless of whether full or regulated deficit irrigation are used.

$\mathrm{T}_{\mathrm{r}}$ was the major component of $\mathrm{ET}_{\mathrm{C}}$, with the $\mathrm{T}_{\mathrm{r}} / \mathrm{ET}_{\mathrm{C}}$ ratio of $93.7 \%$ and $89.8 \%$ for $\mathrm{T} 1$ and $\mathrm{T} 2$ in 2017 , and $93.2 \%$ and $89.9 \%$ in 2018, respectively. Although $\mathrm{T}_{\mathrm{r}}$ and $\mathrm{ET}_{\mathrm{c}}$ decreased for $\mathrm{T} 2$, the $\mathrm{T}_{\mathrm{r}} / \mathrm{ET}_{\mathrm{c}}$ ratio did not decrease significantly, suggesting that the growth-based RDI strategy maintains a higher percentage of crop effective transpiration. The $\mathrm{E}_{\mathrm{s}} / \mathrm{ET}_{\mathrm{c}}$ ratio obtained for $\mathrm{T} 1$ in the two years was $6.3 \%$ and $6.8 \%$, while it was $10.1 \%$ and $10.2 \%$ for $\mathrm{T} 2$, respectively. $\mathrm{T} 2$ caused higher evaporation than $\mathrm{T} 1$ for the reason that $\mathrm{T} 2$ restricted the growth of maize and the $\mathrm{f}_{\mathrm{c}}$ for $\mathrm{T} 2$ was lower than that for $\mathrm{T} 1$ at the mid-season stage and 
late-season stage, causing an increase in the exposed soil area, thus increasing the $E_{\mathrm{s}}$. In the early stage of growth, the $\mathrm{f}_{\mathrm{c}}$ of maize was very low, with $\mathrm{E}_{\mathrm{S}}$ as the major active component, and the $\mathrm{E}_{\mathrm{S}} / \mathrm{ET}_{\mathrm{c}}$ ratio was highest, in the range of $39-49.4 \%$. At the development stage, the evaporation ratio was $9.9-12.2 \%$ in 2017 and $1-1.6 \%$ in 2018 . Such a large difference was due to a decrease of $18.4 \mathrm{~mm}$ in rainfall and a decrease in irrigation volume of $7.2 \mathrm{~mm}$ in the same period in 2018. The $\mathrm{E}_{\mathrm{S}}$ in the mid-growth period in 2017 was smaller than that in the late-growth period, and the opposite was true in 2018. This was because the rainfall in the mid-growth period in 2018 was $140.2 \mathrm{~mm}$, which was $57.6 \mathrm{~mm}$ more than in 2017, which led to an increase in soil evaporation. These results indicated that soil evaporation is greatly affected by the degree and coefficient of soil surface moisture and canopy coverage. For efficient crop water management practices, inefficient water consumption can be minimized by covering the ground with the canopy as soon as possible before performing deficit irrigation.

Table 6. Soil evaporation $\left(E_{s}\right)$, transpiration $\left(T_{r}\right)$, evapotranspiration $\left(E_{c}\right)$ and ratios of evaporation and transpiration to evapotranspiration for the two treatments (T1 and T2) at different growth stages of maize in 2017 and 2018.

\begin{tabular}{|c|c|c|c|c|c|c|c|c|c|c|c|}
\hline \multirow{2}{*}{$\begin{array}{l}\text { Growth } \\
\text { Stages }\end{array}$} & \multirow{2}{*}{ Years } & \multicolumn{2}{|c|}{$E_{s}(m m)$} & \multicolumn{2}{|c|}{$\mathrm{T}_{\mathrm{r}}(\mathrm{mm})$} & \multicolumn{2}{|c|}{$\mathrm{ET}_{\mathrm{c}}(\mathrm{mm})$} & \multicolumn{2}{|c|}{$\mathrm{E}_{\mathrm{s}} / \mathrm{ET}_{\mathrm{c}}(\%)$} & \multicolumn{2}{|c|}{$\mathrm{T}_{\mathrm{r}} / \mathrm{ET}_{\mathrm{c}}(\%)$} \\
\hline & & T1 & $\mathrm{T} 2$ & T1 & T2 & T1 & T2 & T1 & T2 & T1 & T2 \\
\hline \multirow[b]{2}{*}{ Initial } & 2017 & 17.8 & 21.5 & 18.3 & 22.0 & 36.2 & 43.6 & 49.3 & 49.4 & 50.7 & 50.6 \\
\hline & 2018 & 21.0 & 21.0 & 31.9 & 32.9 & 52.9 & 54.0 & 39.7 & 39.0 & 60.3 & 61.0 \\
\hline \multirow{2}{*}{ Development } & 2017 & 7.8 & 10.0 & 70.5 & 71.8 & 78.3 & 81.8 & 9.9 & 12.2 & 90.1 & 87.8 \\
\hline & 2018 & 0.8 & 1.2 & 77.3 & 73.3 & 78.1 & 74.5 & 1.0 & 1.6 & 99.0 & 98.4 \\
\hline \multirow{2}{*}{ Mid-season } & 2017 & 3.9 & 7.9 & 302.9 & 214.2 & 306.9 & 222.1 & 1.3 & 3.5 & 98.7 & 96.5 \\
\hline & 2018 & 5.5 & 8.6 & 306.4 & 218.3 & 311.9 & 226.9 & 1.8 & 3.8 & 98.2 & 96.2 \\
\hline \multirow{2}{*}{ Late-season } & 2017 & 2.4 & 4.2 & 84.2 & 77.2 & 86.6 & 81.4 & 2.8 & 5.2 & 97.2 & 94.8 \\
\hline & 2018 & 7.9 & 12.6 & 68.3 & 62.9 & 76.3 & 75.5 & 10.4 & 16.7 & 89.6 & 83.3 \\
\hline \multirow{2}{*}{ Whole season } & 2017 & 32.0 & 43.6 & 476.0 & 385.3 & 507.9 & 428.9 & 6.3 & 10.2 & 93.7 & 89.8 \\
\hline & 2018 & 35.2 & 43.4 & 484.0 & 387.5 & 519.1 & 430.9 & 6.8 & 10.1 & 93.2 & 89.9 \\
\hline
\end{tabular}

Previous studies have shown that drip irrigation under mulch can effectively reduce soil evaporation, thus improving the effective water use efficiency of crops or increasing $\mathrm{T}_{\mathrm{r}} / \mathrm{ET}_{\mathrm{c}}$, thereby promoting the growth of biomass and yield [23]. Ding et al. [20] found that for maize for seed under film conditions $\left(f_{m}=0.7\right)$ in arid regions of Northwest China, $\mathrm{E}_{\mathrm{S}}$ decreased by $55.7 \%$ compared to film-free conditions, while $\mathrm{T}_{\mathrm{r}}$ was higher. Martins et al. [36] found that the $\mathrm{E}_{\mathrm{S}} / \mathrm{ET}_{\mathrm{C}}$ ratio in a maize field was $8-9 \%$ under drip irrigation with straw mulch. Li et al. [19] found that that the maize $\mathrm{E}_{\mathrm{S}} / \mathrm{ET}_{\mathrm{C}}$ ratio was $19.85-20.29 \%$ with film-mulched treatment but 26.15-27.23\% without mulch in northeastern Inner Mongolia. Kang et al. [43] studied irrigated maize without mulch in the Guanzhong area, concluding that the $\mathrm{E}_{\mathrm{s}} / \mathrm{ET}_{\mathrm{c}}$ ratio was $26 \%$. In this study, the $\mathrm{E}_{\mathrm{s}} / \mathrm{ET}_{\mathrm{c}}$ ratio of the two treatments under the condition of mulching drip irrigation were 6.3-10.2\%, which is lower than the results of previous studies, indicating that drip irrigation under mulching mainly increases the effective transpiration rate of crops by reducing soil evaporation to save water and increase yield.

The $\mathrm{E}_{\mathrm{S}} / \mathrm{ET}_{\mathrm{c}}$ ratios were $10.1 \%$ and $10.2 \%$ for $\mathrm{T} 2$ for the two years, respectively, which is slightly higher than those of $\mathrm{T} 1$, at $6.3-6.8 \%$. We started to implement water deficits in the late growth period after the canopy covered the ground, which might cause leaf curling, reduce the canopy coverage, and increase the area of bare soil and evaporated surface. Comas et al. also found that in addition to reducing crop growth and leaf area, water deficit also increased the proportion of rolled leaves, thereby reducing canopy coverage [27]. In this study, due to the use of drip irrigation under the mulch, the area of irrigated wetness and bare soil was small. Even though RDI reduced the canopy coverage and increased the bare soil area, the actual wet soil evaporation area did not increase, so there was no significant increase in $E_{s}$. These results indicate that in the practices of efficient water 
management for crops, sufficient irrigation in the early stage of growth can be used to quickly cover the ground in the canopy and then implement the strategic stage of RDI. At the same time, combined with high-efficiency water-saving irrigation methods such as drip irrigation under mulch, it can reduce water use but does not increase the proportion of effectless water.

Although our study area is arid and cold with an annual average temperature of $8{ }^{\circ} \mathrm{C}$, our methods and result patterns can be extended to other areas. The purpose of our study was to estimate $\mathrm{ET}_{\mathrm{C}}$ and its components to support irrigation scheduling using the SIMDualKc model based on daily soil water balance. The estimation accuracy can be improved if ones take into account soil water infiltration together with the root water uptake [44-46]. Further work will be needed to incorporate the two processes into dynamic soil water equations, e.g., using the Richards equation, for accurate partitioning of $\mathrm{ET}_{\mathrm{C}}$ and soil water flow.

\section{Conclusions}

A two-year experiment of full irrigation and regulated deficit irrigation of maize with drip irrigation under mulch was conducted in an arid region of Northwest China. The daily evapotranspiration $\left(\mathrm{ET}_{\mathrm{C}}\right)$, soil evaporation $\left(\mathrm{E}_{\mathrm{s}}\right)$, and transpiration $\left(\mathrm{T}_{\mathrm{r}}\right)$ of maize during its whole growth period and their ratios were calculated using the calibrated dual crop coefficient model SIMDualK $\mathrm{c}$. Then, the differences in $\mathrm{ET}_{\mathrm{c}}$ and its components between the two treatments were analyzed, drawing the following conclusions: (1) The SIMDualK $\mathrm{C}_{\mathrm{c}}$ model can well simulate the dynamic variations of soil water content and plant transpiration in the maize field with drip irrigation under mulch, and can be used to calculate the evapotranspiration, soil evaporation, and transpiration of maize during its whole growth period; (2) a local basic crop coefficient was obtained for maize with drip irrigation under mulch in an arid region of Northwest China; (3) drip irrigation under mulch can significantly reduce the proportion of soil evaporation, and increase the proportion of plant transpiration that is effective for crop production. Growth-based strategic RDI can reduce crop water use without significantly increasing the proportion of ineffective soil evaporation.

Author Contributions: Experiment design: C.X. and R.D. Data analysis: C.X., J.S. and Y.L. Contributed reagents/materials/analysis tools: C.X., R.D., J.S. and Y.L. Manuscript writing: C.X., R.D., J.S. and Y.L. All authors have read and agreed to the published version of the manuscript.

Funding: This work was supported by the National Natural Science Foundation of China (51790534 and 52179051) and the China Agriculture Research System of MOF and MARA (CARS-03).

Institutional Review Board Statement: Not applicable.

Informed Consent Statement: Not applicable.

Data Availability Statement: The data presented in this study is available on request from the corresponding author.

Acknowledgments: The authors would like to express their gratitude to the funding agencies, the editor, and reviewers for leveraging the quality of this work, and the students who participated in the fieldwork and laboratory work.

Conflicts of Interest: The authors declare no conflict of interest.

\section{References}

1. Zhao, N.; Liu, Y.; Cai, J.; LS, P. Validation and application of dual crop coefficient model SIMDual_Kc. Trans. Chin. Soc. Agric. Eng. 2011, 27, 89-95.

2. Allen, R.G. Using the FAO-56 dual crop coefficient method over an irrigated region as part of an evapotranspiration intercomparison study. J. Hydrol. 2000, 229, 27-41. [CrossRef]

3. Zhao, L.; Ji, X. Quantification of transpiration and evaporation over agricultural field using the FAO-56 dual crop coefficient approach-a case study of the maize field in an oasis in the middlestream of the Heihe River basin in Northwest China. Sci. Agric. Sin. 2010, 43, 4016-4026. 
4. Pieruschka, R.; Huber, G.; Berry, J.A. Control of transpiration by radiation. Proc. Natl. Acad. Sci. USA 2010, 107, 13372-13377. [CrossRef] [PubMed]

5. Allen, R.G.; Pereira, L.S.; Raes, D.; Smith, M. Crop Evapotranspiration-Guidelines for Computing Crop Water Requirements-FAO Irrigation and Drainage Paper 56; FAO: Rome, Italy, 1998; Volume 300, p. D05109.

6. Fan, Y.; Cai, H. Comparison of crop water requirements computed by single crop coefficient approach and dual crop coefficient approach. J. Hydraul. Eng. 2002, 3, 50-54.

7. Lu, X.; Duan, S.; Ma, X.; Bai, S. A comparative study between single crop coefficient method and double crop coefficient method in calculation of water requirement of maize. Water Sav. Irrig. 2012, 11, 18-21.

8. Shi, J.; Gong, D.; Mei, X.; Hao, W.; Ma, X.; Hu, X. Research progress in surface evapotranspiration measuring and partitioning methods. China Rural Water Hydropower 2012, 2, 49-53,59.

9. Rosa, R.D.; Paredes, P.; Rodrigues, G.C.; Alves, I.; Fernando, R.M.; Pereira, L.S.; Allen, R.G. Implementing the dual crop coefficient approach in interactive software. 1. Background and computational strategy. Agric. Water Manag. 2012, 103, 8-24. [CrossRef]

10. Fandiño, M.; Olmedo, J.L.; Martínez, E.M.; Valladares, J.; Paredes, P.; Rey, B.J.; Mota, M.; Cancela, J.J.; Pereira, L.S. Assessing and modelling water use and the partition of evapotranspiration of irrigated hop (Humulus Lupulus), and relations of transpiration with hops yield and alpha-acids. Ind. Crop Prod. 2015, 77, 204-217. [CrossRef]

11. Giménez, L.; Petillo, M.G.; Paredes, P.; Pereira, L.S. Predicting maize transpiration, water use and productivity for developing improved supplemental irrigation schedules in western Uruguay to cope with climate variability. Water 2016, 8, 309. [CrossRef]

12. Paredes, P.; Rodrigues, G.C.; Alves, I.; Pereira, L.S. Partitioning evapotranspiration, yield prediction and economic returns of maize under various irrigation management strategies. Agric. Water Manag. 2014, 135, 27-39. [CrossRef]

13. Qiu, R.; Du, T.; Kang, S.; Chen, R.; Wu, L. Assessing the SIMDualKc model for estimating evapotranspiration of hot pepper grown in a solar greenhouse in Northwest China. Agric. Syst. 2015, 138, 1-9. [CrossRef]

14. Wei, Z.; Paredes, P.; Liu, Y.; Chi, W.W.; Pereira, L.S. Modelling transpiration, soil evaporation and yield prediction of soybean in North China Plain. Agric. Water Manag. 2015, 147, 43-53. [CrossRef]

15. Wu, Y.; Liu, T.; Paredes, P.; Duan, L.; Wang, H.; Wang, T.; Pereira, L.S. Ecohydrology of groundwater-dependent grasslands of the semi-arid Horqin sandy land of inner Mongolia focusing on evapotranspiration partition. Ecohydrology 2016, 9, $1052-1067$. [CrossRef]

16. Wang, Z.; Cai, H.; Yu, L.; Wang, X.; Shi, X. Estimation of evapotranspiration and soil evaporation of winter wheat in arid region of Northwest China based on SIMDualKC model. Trans. Chin. Soc. Agric. Eng. 2016, 32, 126-136.

17. Yan, H.; Wu, H.; Zhang, C.; Acquah, S.; Zhao, B.; Huang, S. Estimation of greenhouse cucumber evapotranspiration in different seasons based on modified dual crop coefficient model. Trans. Chin. Soc. Agric. Eng. 2018, 34, 117-125.

18. Zhang, Y.; Wang, J.; Gong, S.; Xu, D.; Sui, J.; Wu, Z. Analysis of water saving and yield increasing mechanism in maize field with drip irrigation under film mulching based on transpiration estimated by sap flow meter. Trans. Chin. Soc. Agric. Eng. 2018, 34, 89-97.

19. Li, R.; Zhao, J.; Shi, H.; Wang, N.; Qi, Y.; Feng, Y.; Jia, Q. Simulation of evapotranspiration of corn under mulched drip irrigation based on SIMDual_Kc model in Tongliao area of Inner Mongolia. Trans. Chin. Soc. Agric. Eng. 2018, 34, 127-134.

20. Ding, R.; Kang, S.; Zhang, Y.; Hao, X.; Tong, L.; Du, T. Partitioning evapotranspiration into soil evaporation and transpiration using a modified dual crop coefficient model in irrigated maize field with ground-mulching. Agric. Water Manag. 2013, 127, 85-96. [CrossRef]

21. Hou, X.; Wang, F.; Han, J.; Kang, S.; Feng, S. Duration of plastic mulch for potato growth under drip irrigation in an arid region of Northwest China. Agric. Forest Meteor. 2010, 150, 115-121. [CrossRef]

22. Zhou, L.; Li, F.; Jin, S.; Song, Y. How two ridges and the furrow mulched with plastic film affect soil water, soil temperature and yield of maize on the semiarid Loess Plateau of China. Field Crops Res. 2009, 113, 41-47. [CrossRef]

23. Fan, Y.; Ding, R.; Kang, S.; Hao, X.; Du, T.; Tong, L.; Li, S. Plastic mulch decreases available energy and evapotranspiration and improves yield and water use efficiency in an irrigated maize cropland. Agric. Water Manag. 2017, 179, 122-131. [CrossRef]

24. Zhang, Y.; Wang, J.; Gong, S.; Xu, D.; Sui, J.; Wu, Z.; Mo, Y. Effects of film mulching on evapotranspiration, yield and water use efficiency of a maize field with drip irrigation in Northeastern China. Agric. Water Manag. 2018, 205, 90-99. [CrossRef]

25. Cai, H.; Kang, S.; Zhang, Z.; Chai, H.; Hu, X.; Wang, J. Proper growth stages and deficit degree of crop regulated deficit irrigation. Trans. Chin. Soc. Agric. Eng. 2000, 16, 24-27.

26. Trout, T.J.; DeJonge, K.C. Water productivity of maize in the US high plains. Irrig. Sci. 2017, 35, 251-266. [CrossRef]

27. Comas, L.H.; Trout, T.J.; DeJonge, K.C.; Zhang, H.; Gleason, S.M. Water productivity under strategic growth stage-based deficit irrigation in maize. Agric. Water Manag. 2019, 212, 433-440. [CrossRef]

28. Rosa, R.D.; Paredes, P.; Rodrigues, G.C.; Fernando, R.M.; Alves, I.; Pereira, L.S.; Allen, R.G. Implementing the dual crop coefficient approach in interactive software: 2. Model testing. Agric. Water Manag. 2012, 103, 62-77. [CrossRef]

29. Zhao, N.; Liu, Y.; Cai, J.; Paredes, P.; Rosa, R.D.; Pereira, L.S. Dual crop coefficient modelling applied to the winter wheat-summer maize crop sequence in North China Plain: Basal crop coefficients and soil evaporation component. Agric. Water Manag. 2013, 117, 93-105. [CrossRef]

30. Legates, D.R.; McCabe, G.J., Jr. Evaluating the use of "goodness-of-fit" Measures in hydrologic and hydroclimatic model validation. Water Resour. Res. 1999, 35, 233-241. [CrossRef] 
31. Moriasi, D.N. Model evaluation guidelines for systematic quantification of accuracy in watershed simulations. Trans. ASABE 2007, 50, 885-900.

32. Xu, D.; Mermoud, A. Modeling the soil water balance based on time-dependent hydraulic conductivity under different tillage practices. Agric. Water Manag. 2003, 63, 139-151. [CrossRef]

33. Zhang, B.; Liu, Y.; Xu, D.; Zhao, N.; Lei, B.; Rosa, R.D.; Paredes, P.; Paço, T.A.; Pereira, L.S. The dual crop coefficient approach to estimate and partitioning evapotranspiration of the winter wheat-summer maize crop sequence in North China Plain. Irrig. Sci. 2013, 31, 1303-1316. [CrossRef]

34. Pereira, L.S.; Paredes, P.; Hunsaker, D.J.; López-Urrea, R.; Mohammadi Shad, Z. Standard single and basal crop coefficients for field crops. Updates and advances to the FAO56 crop water requirements method. Agric. Water Manag. 2021, $243,106466$. [CrossRef]

35. Chauhdary, J.N.; Bakhsh, A.; Ragab, R.; Khaliq, A.; Engel, B.A.; Rizwan, M.; Shahid, M.A.; Nawaz, Q. Modeling corn growth and root zone salinity dynamics to improve irrigation and fertigation management under semi-arid conditions. Agric. Water Manag. 2020, 230, 105952. [CrossRef]

36. Martins, J.D.; Rodrigues, G.C.; Paredes, P.; Carlesso, R.; Oliveira, Z.B.; Knies, A.E.; Petry, M.T.; Pereira, L.S. Dual crop coefficients for maize in southern Brazil: Model testing for sprinkler and drip irrigation and mulched soil. Biosyst. Eng. 2013, 115, 291-310. [CrossRef]

37. Rodrigues, G.C.; Paredes, P.; Gonçalves, J.M.; Alves, I.; Pereira, L.S. Comparing sprinkler and drip irrigation systems for full and deficit irrigated maize using multicriteria analysis and simulation modelling: Ranking for water saving vs. farm economic returns. Agric. Water Manag. 2013, 126, 85-96. [CrossRef]

38. Paredes, P.; de Melo-Abreu, J.P.; Alves, I.; Pereira, L.S. Assessing the performance of the FAO AquaCrop model to estimate maize yields and water use under full and deficit irrigation with focus on model parameterization. Agric. Water Manag. 2014, 144, 81-97. [CrossRef]

39. Yan, S.; Zhang, F.; Wu, Y.; Qiang, S.; Zou, H.; Xiang, Y.; Fan, J.; Tian, J. Estimation of drip irrigated summer maize soil water content and evapotranspiration based on SIMDualKc model. Trans. Chin. Soc. Agric. Eng. 2017, 33, 152-160.

40. Zhao, N.; Liu, Y.; Cai, J.; Yu, F.; Li, C. Research on soil evaporation of summer maize by field measurement and model simulation. Trans. Chin. Soc. Agric. Eng. 2012, 28, 66-73.

41. Wu, Y.; Liu, T.; Paredes, P.; Duan, L.; Pereira, L.S. Water use by a groundwater dependent maize in a semi-arid region of Inner Mongolia: Evapotranspiration partitioning and capillary rise. Agric. Water Manag. 2015, 152, 222-232. [CrossRef]

42. Qiu, R.; Du, T.; Chen, R. Application of the dual crop coefficient model for estimating tomato evapotranspiration in greenhouse. J. Hydaul. Eng. 2015, 46, 678-686.

43. Kang, S.; Gu, B.; Du, T.; Zhang, J. Crop coefficient and ratio of transpiration to evapotranspiration of winter wheat and maize in a semi-humid region. Agric. Water Manag. 2003, 59, 239-254. [CrossRef]

44. Difonzo, F.V.; Masciopinto, C.; Vurro, M.; Berardi, M. Shooting the numerical solution of moisture flow equation with root water uptake models: A python tool. Water Resour. Manag. 2021, 35, 2553-2567. [CrossRef]

45. De Melo, M.L.A.; de Jong van Lier, Q. Revisiting the Feddes reduction function for modeling root water uptake and crop transpiration. J. Hydrol. 2021, 603, 126952. [CrossRef]

46. Wu, X.; Zuo, Q.; Shi, J.; Wang, L.; Xue, X.; Ben-Gal, A. Introducing water stress hysteresis to the Feddes empirical macroscopic root water uptake model. Agric. Water Manag. 2020, 240, 106293. [CrossRef] 